\title{
Body Image Distress and Its Associations From an International Sample of Men and Women Across the Adult Life Span: Web-Based Survey Study
}

Alyssa Milton ${ }^{1,2 *}$, BSc, MAppSc, PhD; Ashlea Hambleton ${ }^{3,4^{*}}$, BPsych, MClinPsych; Anna Roberts ${ }^{1,3}$, BAppSc, MExSc, MBMSc; Tracey Davenport ${ }^{1,3}$, BA, eMBA; Anna Flego ${ }^{5}$, BPT, MPH; Jane Burns ${ }^{3}$, PhD; Ian Hickie ${ }^{1}$, AM, $\mathrm{MD}$

${ }^{1}$ Brain and Mind Centre, The University of Sydney, Sydney, Australia

${ }^{2}$ Sydney School of Medicine, Faculty of Medicine and Health, University of Sydney, Camperdown, Australia

${ }^{3}$ Project Synergy, InnoWell Pty Ltd, Sydney, Australia

${ }^{4}$ Inside Out Institute for Eating Disorders, Charles Perkins Centre, University of Sydney, Sydney, Australia

${ }^{5}$ The Movember Foundation, Australia, East Melbourne, Australia

*these authors contributed equally

\section{Corresponding Author:}

Alyssa Milton, BSc, MAppSc, PhD

Sydney School of Medicine

Faculty of Medicine and Health

University of Sydney

Professor Marie Bashir Centre

67-73 Missenden Rd

Camperdown, 2050

Australia

Phone: 610293510774

Email: alyssa.milton@sydney.edu.au

\section{Abstract}

Background: Previous research on body image distress mainly relied on samples that were small, generally homogeneous in age or sex, often limited to one geographical region, and were characterized by a lack of comprehensive analysis of multiple psychosocial domains. The research presented in this paper extends the international literature using the results of the web-based Global Health and Wellbeing Survey 2015. The survey included a large sample of both men and women aged $\geq 16$ years from Australia, Canada, New Zealand, the United Kingdom, or the United States.

Objective: The main objectives of this study are to examine body image distress across the adult life span ( $\geq 16$ years) and sex and assess the association between body image distress and various psychosocial risk and protective factors.

Methods: Data were extracted from the Global Health and Wellbeing Survey 2015, a web-based international self-report survey with 10,765 respondents, and compared with previous web-based surveys conducted in 2009 and 2012.

Results: The body image distress of young Australians (aged 16-25 years) significantly rose by $33 \%$ from 2009 to 2015 . In 2015, 75.19\% (961/1278) of 16- to 25-year-old adults reported body image distress worldwide, and a decline in body image distress was noted with increasing age. More women reported higher levels of body image distress than men (1953/3338, 58.51\% vs $853 / 2175,39.22 \%$ ). Sex, age, current dieting status, perception of weight, psychological distress, alcohol and other substance misuse, and well-being significantly explained $24 \%$ of the variance in body image distress in a linear regression $\left(F_{15,4966}=105.8\right.$; $P<.001)$.

Conclusions: This study demonstrates the significant interplay between body image distress and psychosocial factors across age and sex.

(JMIR Form Res 2021;5(11):e25329) doi: 10.2196/25329 


\section{KEYWORDS}

body image; mental health; well-being; web-based survey; sex differences; age

\section{Introduction}

\section{Background}

There is a clear need to understand and address body image distress, particularly when considering the increasing prevalence rates of body image distress worldwide [1-3] and the noted relationship between body image distress and mental ill-health [4]. Furthermore, there is scant large-scale international research examining body image across the adult life span [4] and from the perspectives of both men and women [5].

Body image is a multifaceted construct encompassing one's body-related self-perceptions and self-attitudes, including thoughts, feelings, behaviors, and beliefs toward the body [6]. Research suggests that body image dissatisfaction occurs when there is a discrepancy between how an individual views their body (actual body image) and how they want it to be (ideal body image) [7,8]. Dissatisfaction, overevaluation, and preoccupation are considered as contributing factors to body image distress [9]. Current body ideals predominantly promote thinness for women and muscularity for men [10,11]. Given the difference between current body ideals and the actual body shape and size of most of the population, it is not surprising that many people view their bodies negatively and experience distress because of this negative self-perception [12].

\section{Body Image Distress Over Time}

Body image is ranked as a top concern for young people [13]. Research suggests that the proportion of the population experiencing increased body image distress is increasing. It has been well documented that viewing appearance-focused media contributes to the development of body image concerns [14,15]. In the past 10 years, there has been a stark rise in multimedia platforms, such as Instagram, Snapchat, and TikTok. The imagery on social media is often filtered and edited in a way that promotes an unrealistic appearance ideal. Research has shown that social media use is associated with increased body image dissatisfaction [14] because it facilitates comparison, and appearance-related comments and praise are reinforced with likes, follows, and comments.

\section{Body Image, Age, and Sex}

The association between weight status (as measured by BMI) and body image dissatisfaction has been previously explored [16]. Research has demonstrated that increased BMI is associated with greater body image dissatisfaction in college students [17], help-seeking adults [18], adolescent men [19], and nonclinical samples of adult women [20]. Risk of body dissatisfaction is not restricted to individuals with higher BMI; adolescent women with either a healthy or an overweight BMI experience higher levels of body dissatisfaction, whereas underweight women have the highest levels of body satisfaction [19]. Similarly, in a sample of middle-aged women, $70 \%$ of participants reported a desire to be thinner, despite most being considered normal weight [21]. Overall, these findings fit the current cultural narrative that a thin body is both desirable and idealized in Western societies [22].

Although the research has mainly focused on young women, some studies indicate that body image concerns are pervasive across the adult life span [12] for both sexes [5]. The picture appears to be more complex for men [23]. For example, adolescent men tend to be equally divided between wanting to lose weight (predominantly high body fat) and gain weight (muscle mass) [5,24]. As men move into adulthood, there is an increase in the desire to lose weight [5]. Within cohorts of middle-aged women, only $11 \%$ of participants endorsed being satisfied with their bodies [25]. Women's dissatisfaction with their bodies appears relatively stable across the adult life span $[8,12]$. However, some research suggests that the impact of body image on an individual's self-esteem and self-concept may diminish over time [26]. Furthermore, there is more tolerance in what body sizes are considered acceptable with increasing age [4,27]. However, overall, body image research looking at age, sex, and weight is fragmented, and a comprehensive picture is lacking.

\section{Body Image Distress and Psychopathology}

Body image dissatisfaction in childhood and early adolescence can predict adverse health outcomes in later life, including engaging in dangerous weight control behaviors and general psychological distress [28]. As highlighted above, research with adolescents is much more extensive than with their adult counterparts, with several studies demonstrating an association between body dissatisfaction and anxiety [29-33], depression [29,30,34-37], self-harm [38-42], and low self-esteem $[28,36,37]$.

Research has reported that body image dissatisfaction is associated with higher levels of depression, anxiety, disordered eating [43-45], and distress [46]. Furthermore, research has identified associations between body image with other aspects of health, such as tobacco smoking [47], alcohol misuse [48], poor self-esteem $[18,49,50]$, and poor mental and physical health-related quality of life [46].

Conversely, optimism, positive affect, self-compassion, life satisfaction, and subjective happiness [51-61] are associated with positive body image. Social well-being has also been reported to play a part in both positive and negative body image, particularly in adolescents [59,62-64]. For example, Bearman et al [63] observed higher levels of body dissatisfaction in girls and boys who had deficits in their social support from parents and peers. Meanwhile, individuals with more supportive parental relationships have reported higher body image satisfaction [62].

\section{Current Research}

Previous research exploring body image distress mainly relied on small samples that were generally homogeneous in age or sex, lacked a comprehensive analysis of multiple psychosocial domains, and were limited to one geographical region. This study extends the international literature using the results of the Global Health and Wellbeing Survey 2015, a large web-based 
sample of both men and women (aged $\geq 16$ years) from Australia, Canada, New Zealand, the United Kingdom, or the United States. Additional data sources included the headspace web-based Community Youth Survey (2009) and the Young and Well First National Survey on the web (2012).

This study has 3 main aims, including the assessment of (1) the changes in body image distress over time (between 2009 and 2015) for young people aged 16 to 25 years; (2) the associations between weight range (BMI), dieting status, and perceived body image distress by sex and age group; and (3) the association of various demographic, health, and well-being factors with body image distress or preoccupation.

\section{Methods}

\section{Participants}

Participants were a voluntary community sample of men and women (aged $\geq 16$ years) who reported that they had lived in 1 of the 5 target countries (Australia, Canada, New Zealand, the United Kingdom, or the United States) for the best part of the past 12 months. A total of 16,510 people reviewed the consent and eligibility screen. Of the 16,510 people, the total eligible sample was $10,765(65.2 \%)$ respondents. Of those excluded, $26.2 \%(4326 / 16,510)$ did not consent to participate, and $4.3 \%$ $(710 / 16,510)$ were younger than 16 years.

\section{Procedures and Recruitment}

The primary study received institutional ethics approval from The University of Sydney Human Research Ethics Committee (protocol 2015/412). All procedures complied with the ethical standards of the relevant national and institutional committees on human ethics and the Helsinki Declaration of 1975, as revised in 2008 .

The survey was hosted on the internet from July 1, 2015, to December 11, 2015. For optimizing recruitment in the 5 target countries, the following strategies were used: both paid and free advertising across multiple social media channels such as Facebook, Twitter, and YouTube for survey dissemination [65]; layering of recruitment messages [66]; passive web-based snowballing via social media to spread study information through sharing, liking, and tweeting [65,67]; and traditional snowballing [68]. Targeted recruitment based on age, sex, and region was carried out through paid advertising channels to maximize responses from groups hard to reach. Respondents consented on the website and were informed that their responses were confidential, nonidentifiable, and that they could cease participation at any time. Participants were informed that the survey would take between 20 and 45 minutes to complete depending on participant answers and the survey skip pattern. Any respondents indicating psychological distress or problematic alcohol or substance use in their responses were provided with the contact details of local support lines.

\section{Materials}

Items in this substudy were extracted from the Global Health and Wellbeing Survey 2015 [69], and where items could be compared, from the headspace web-based Community Youth Survey (2009) and the Young and Well First National Survey on the web (2012). Areas of interest specific to this substudy are described in the following sections.

\section{Demographics}

The respondents first provided their sex (men and women) and age (16-25 years, 26-49 years, or $\geq 50$ years).

\section{Weight, Body Image, and Eating Behaviors}

BMI was determined by asking respondents their weight ( $\mathrm{kg}$ or lb) and height (meters or feet and inches). Respondents with a BMI less than 18.5 were classified as underweight, a BMI between 18.5 and 24.9 as healthy weight, a BMI between 25.0 and 29.9 as overweight, and a BMI higher than 30.0 as obese.

Current dieting status was determined by the question "Are you currently dieting?" adapted from Blashill and Wilhelm [70]; this item provided 3 response options ("yes, to lose weight"; "yes, to gain weight"; and "no").

For assessing body image attitudes, respondents were asked to self-evaluate the importance of weight and shape for them over the past 3 months: "How much has your shape influenced how you feel as a person?" This question was answered on a 6-point Likert scale ranging from not at all to a great deal.

For assessing body image distress or preoccupation, respondents were asked, "Do you get very distressed or preoccupied by any specific aspect of your physical appearance?" using a dichotomous yes or no response option. If respondents indicated distress or preoccupation, a follow-up question asked which areas of their body they were concerned about, such as facial features, arms or legs, and weight [71]. This body image distress item was also asked in the web-based headspace Community Youth Survey in 2009 and the Young and Well National Survey on the web in 2012 with 16- to 25-year-old adults [71]. These data were used in this research for longitudinal cohort comparisons.

\section{Mental Health and Well-being}

Physical activity was measured by the International Physical Activity Questionnaire short form, which classifies individuals into 1 of 3 levels of physical activity (inactive vs minimally active vs health-enhancing physical activity) [72].

Current psychological distress was measured using the 10-item Kessler Psychological Distress Scale (K10) [73]. Total scores were grouped into 4 levels of psychological distress (10-15=low, 16-21=moderate, 22-29=high, and 30-50=very high) [74].

Respondents' levels of suicidal thoughts and behaviors in the past 12 months were measured using the 5-item suicidal thoughts and acts subscale from the Psychiatric Symptom Frequency Scale [75].

The likelihood of alcohol or other substance misuse was calculated using 2 items. If respondents positively endorsed one of either item, "...recently thought that you should cut down..." or "...another person suggested you should cut down...," they were categorized as having a possible alcohol or other substance misuse. Endorsement of both items resulted in probable alcohol or other substance misuse. Endorsement of neither item resulted in being placed in the not likely category. 
Days out of role was extracted from the Brief Disability Questionnaire [76] to investigate functioning. The 7-item Personal Well-being Index [77] was used to assess subjective well-being.

Happiness was measured by the 4-item Oxford Happiness Questionnaire [78], and resilience was measured by the 4-item Brief Resilience Coping Scale [79].

Perceived social support and conflict in close relationships were measured by the 5-item Schuster Social Support and Conflict Scale [80].

\section{Analysis}

Survey data were prepared and analyzed using IBM SPSS Statistics for Windows, Version 22.0 (IBM Corp, 2013). For addressing aim 1, body image distress data in 2009 and 2012 were compared with 2015 data using a one-sample two-tailed $t$ test. To address aim 2, descriptive and frequency statistics were used to describe all weight, dieting, and body image items by basic demographics (sex and age). Chi-square and analysis of variance tests were completed to compare items by sex and age. For addressing aim 3, an initial scoping analysis using Pearson product-moment $r$ correlations [81] was conducted to independently assess the strength of the relationship between body image distress and these health and well-being items (healthy weight; no vs yes based on BMI data), current dieting status (no vs yes), perception of weight (about the right weight vs all others), physical activity (International Physical Activity Questionnaire short form), psychological distress (K10), suicidal ideation (Psychiatric Symptom Frequency Scale), alcohol and/or other substance misuse, days out of role, well-being (Personal Well-being Index), happiness (Oxford Happiness Questionnaire), resilience (Brief Resilience Coping Scale), intimate bonds (Intimate Bond Measure), and social support (Social Support and Conflict Scale). A subsequent linear regression analysis was conducted to determine which of the health and well-being items significantly explained variance in body image distress when considered together while controlling for sex and age.

\section{Results}

\section{Respondent Participation Rates and Characteristics}

Most of the eligible respondents were women $(6464 / 10,765$, $60.05 \%)$. Of the 10,753 respondents, $2874(26.73 \%)$ were aged between 16 and 25 years, $2879(26.77 \%)$ were aged between 26 and 49 years, and $5000(46.49 \%)$ were aged $\geq 50$ years. A breakdown of demographics by country, age, and sex is presented in Table 1. Further demographic details can be found in related publications $[82,83]$.

Table 1. Participant demographics by country, age, and sex $(\mathrm{N}=10,765)$.

\begin{tabular}{lllllll}
\hline Characteristics & Total & Australia & Canada & New Zealand & United Kingdom & United States \\
\hline $\begin{array}{l}\text { Country, n (\%) } \\
\text { Sex, } \mathbf{n}(\%)\end{array}$ & $10,765(100)$ & $3349(31.11)$ & $1888(17.54)$ & $1752(16.27)$ & $1938(18)$ & $1838(17.07)$ \\
$\quad$ Women & $6464(60.05)$ & $2067(61.72)$ & $1097(58.1)$ & $1055(60.22)$ & $1176(60.68)$ & $1069(58.16)$ \\
$\quad$ Men & $4301(39.95)$ & $1282(38.28)$ & $791(41.89)$ & $697(39.78)$ & $762(39.32)$ & $769(41.84)$ \\
Age (years), mean (SD) & $44.37(19.68)$ & $42.44(18.71)$ & $52.46(17.84)$ & $39.65(19.51)$ & $42.57(19.40)$ & $45.97(21.07)$ \\
\hline
\end{tabular}

\section{Main Findings}

\section{Aim 1: Changes in Body Image Distress Over Time Across the Life Span}

Of those young Australians (aged 16-25 years) who completed the 2009 (headspace web-based Community Youth Survey), 2012 (Young and Well First National Survey on the web), or 2015 (Global Health and Wellbeing Survey) surveys, self-reported body image distress rose by $33 \%$ from 2009 to 2015 (419/949, 44.2\% reported distress in 2009; 1158/1731, $66.89 \%$ in 2012 ; and $300 / 388,77.32 \%$ in 2015 ). The mean difference was significant across both the 2009 and 2012 time points (2009 vs 2015: $t_{387}=15.56, P<.001 ; 2012$ vs 2015: $\left.t_{387}=4.90, P<.001\right)$.

\section{Aim 2: Body Image, BMI, and Dieting by Age and Sex}

Table 2 displays frequency statistics for measures of body image items, BMI, and current dieting status by age band and sex from the Global Health and Wellbeing Survey 2015. Significance tests comparing items across sex and age are presented in Multimedia Appendix 1. Approximately half of all respondents $(2806 / 5513,50.89 \%)$ reported feeling very distressed or preoccupied with their body image. Women reported higher levels of distress related to body image than men (1953/3338, $58.51 \%$ vs $853 / 2175,39.22 \%$ ). Respondents aged $16-25$ years showed higher levels of body image distress than all other age groups, at $75.19 \%$ (961/1278), with distress decreasing as age increased. 
Table 2. Frequency statistics for measures of body image item by age and sex (maximum N=5517).

\begin{tabular}{|c|c|c|c|c|c|c|}
\hline \multirow[t]{2}{*}{ Body image item } & \multicolumn{2}{|l|}{ Sex } & \multicolumn{3}{|c|}{ Age bands (years) } & \multirow[t]{2}{*}{ Full sample } \\
\hline & Men & Women & $16-25$ & $26-49$ & $\geq 50$ & \\
\hline $\begin{array}{l}\text { Body image distress or preoccu- } \\
\text { pation, } \mathrm{n}(\%)\end{array}$ & $2175(39.45)$ & $3338(60.55)$ & $1278(23.18)$ & $1502(27.24)$ & $2733(49.57)$ & $5513(100)$ \\
\hline Yes & $853(39.22)$ & $1953(58.51)$ & $961(75.19)$ & $837(55.73)$ & $1008(36.88)$ & $2806(50.89)$ \\
\hline No & $1322(60.78)$ & $1385(41.49)$ & $317(24.8)$ & $665(44.27)$ & $1725(63.12)$ & $2707(49.1)$ \\
\hline $\begin{array}{l}\text { How much does weight or shape } \\
\text { influence how you think of } \\
\text { yourself as a person }\end{array}$ & $2169(39.47)$ & $3327(60.53)$ & $1275(23.19)$ & $1497(27.24)$ & $2724(49.56)$ & $5496(100)$ \\
\hline $1=$ not at all, n (\%) & $510(23.51)$ & $425(12.77)$ & $130(10.17)$ & $181(12.09)$ & $624(22.91)$ & $935(17.01)$ \\
\hline $6=a$ great deal, $\mathrm{n}(\%)$ & $256(11.8)$ & $771(23.17)$ & $330(25.88)$ & $321(21.44)$ & $376(13.8)$ & $1027(18.69)$ \\
\hline Score, median (IQR) & $3(2-4)$ & $4(2-5)$ & $4(3-6)$ & $4(2-5)$ & $3(2-5)$ & $4(2-5)$ \\
\hline BMI, n (\%) & $2115(39.32)$ & $3264(60.68)$ & $1248(23.2)$ & $1464(27.22)$ & $2667(49.58)$ & $5379(100)$ \\
\hline Underweight & $30(1.42)$ & $141(4.32)$ & $97(7.77)$ & $39(2.67)$ & $35(1.31)$ & $171(3.18)$ \\
\hline Healthy weight & $671(31.73)$ & $1344(41.19)$ & $721(57.77)$ & $580(39.64)$ & 714 (26.77) & $2015(37.47)$ \\
\hline Overweight & $791(37.39)$ & $836(25.62)$ & $232(18.59)$ & $438(29.94)$ & $957(35.88)$ & $1627(30.25)$ \\
\hline Obese & $623(29.46)$ & $842(28.87)$ & $198(15.87)$ & $406(27.75)$ & $961(36.03)$ & 1565 (29.09) \\
\hline Self-evaluation of weight, $n(\%)$ & $2176(39.46)$ & $3339(60.54)$ & $1279(23.19)$ & $1503(27.25)$ & $2733(49.56)$ & $5515(100)$ \\
\hline Very underweight & $25(1.15)$ & $19(0.56)$ & $16(1.25)$ & $9(0.59)$ & $19(0.69)$ & $44(0.79)$ \\
\hline Slightly underweight & $154(7.08)$ & $143(4.28)$ & $129(10.09)$ & $74(4.92)$ & $94(3.44)$ & $297(5.39)$ \\
\hline About the right weight & $646(29.69)$ & $1057(31.66)$ & $574(44.88)$ & $522(34.73)$ & $607(22.21)$ & $1703(30.88)$ \\
\hline Slightly overweight & $1000(45.96)$ & $1348(40.37)$ & $429(33.54)$ & $624(41.52)$ & $1295(47.38)$ & $2348(42.57)$ \\
\hline Very overweight & $351(16.13)$ & $772(23.12)$ & $131(10.24)$ & $274(18.23)$ & $718(26.27)$ & $1123(20.36)$ \\
\hline Currently dieting, $n(\%)$ & $2178(39.48)$ & $3339(60.52)$ & $1278(23.16)$ & $1503(27.24)$ & $2736(49.59)$ & $5517(100)$ \\
\hline Yes, to lose weight & $427(19.61)$ & $868(25.99)$ & $268(20.97)$ & $374(24.88)$ & $653(23.87)$ & $1295(23.47)$ \\
\hline Yes, to gain weight & $49(2.25)$ & $27(0.81)$ & $38(2.97)$ & $17(1.13)$ & $21(0.77)$ & $76(1.38)$ \\
\hline No & $1702(78.15)$ & $2444(73.20)$ & $972(76.06)$ & $1112(73.99)$ & $2062(75.37)$ & $4146(75.15)$ \\
\hline
\end{tabular}

Only $17.01 \%(935 / 5496)$ of respondents in the full sample indicated that their weight and shape did not influence how they thought of themselves as a person. Women $(425 / 3327,12.77 \%)$ and the younger age bands (16-25 years: 130/1275, 10.19\%; 25-44 years: 181/1497, 12.09\%) were significantly less likely to endorse that their weight or shape did not influence their self-perception $(P<.001)$.

Although $57.77 \%(721 / 1248)$ of young people (16-25 years) were in the healthy BMI range, fewer (574/1279, 44.88\%) considered themselves about the right weight. This pattern was repeated in women, of whom $41.19 \%(1344 / 3264)$ were in the healthy BMI range, but fewer $(1057 / 3339,31.66 \%)$ endorsed that they were about the right weight. The percentage of men who were in a healthy BMI range was $31.73 \%(671 / 2115)$, which reflected the rates of men who felt they were about the right weight $(646 / 2176,29.69 \%)$. In the older age brackets, more participants were in the obese BMI category (26-49 years: $406 / 1464,27.75 \%$; $\geq 50$ years: $961 / 2667,36.03 \%$ ) than those who felt that they were very overweight (26-49 years: $274 / 1503$, $18.23 \%$; $\geq 50$ years: $718 / 2733,26.27 \%$ ). Across the full sample, $23.47 \%(1295 / 5517)$ of all participants were currently dieting to lose weight, and $1.38 \%$ (76/5517) were currently dieting to gain weight. Across ages, not engaging in any dieting was relatively consistent (between 1112/1503, 73.99\% and 972/1278, $76.06 \%$ ). Women reported they were dieting to lose weight significantly more frequently $(868 / 3339,25.99 \%)$ than men (427/2178, 19.61\%; $P<.001)$.

For addressing aim 3, a series of linear regressions were conducted to examine the relationship between body image distress or preoccupation and health and well-being items. Table 3 presents the full sample results (Multimedia Appendix 2 for each age group). Individual Pearson product-moment $r$ correlations for each health and well-being item by body image distress are presented in Multimedia Appendix 3. The regression model using the full sample significantly accounted for $24 \%$ of the variance in body image distress or preoccupation $\left(F_{15,4966}=105.8 ; P<.001 ; R_{\text {adj }}^{2}=0.24\right)$. After controlling for sex $(\beta=.12 ; \quad P<.001)$ and age $(\beta=-0.24 ; P<.001), 5$ variables significantly explained model variance. This included current dieting status $(\beta=.13 ; P<.001)$, perception of weight $(\beta=.09$; $P<.001)$, psychological distress $(\beta=.21 ; P<.001)$, alcohol and/or other substance misuse $(\beta=.04 ; P<.001)$, and well-being $(\beta=-0.07 ; P<.001)$. Specifically, respondents who were currently dieting reported body image distress or preoccupation more 
frequently. Those who did not report that they were about the right weight reported higher psychological distress and had a higher likelihood of problematic alcohol or other substance use and higher body image distress or preoccupation. Participants with higher personal well-being scores reported lower levels of body image distress or preoccupation.

Table 3. Linear regression of body image distress $\left(F_{15,4966}=105.8 ; P<.001 ; R^{2}{ }_{\text {adj }}=0.24\right)$.

\begin{tabular}{|c|c|c|c|}
\hline Variable & $t(d f)^{\mathrm{a}}$ & $P$ value & $\beta(95 \% \mathrm{CI})$ \\
\hline \multicolumn{4}{|l|}{ Body image distress or preoccupation } \\
\hline Healthy weight (no vs yes based on BMI) & 0.04 & .97 & $.00(-0.03$ to 0.03$)$ \\
\hline Current dieting (no vs yes) & 10.20 & $<.001$ & $.13(0.12$ to 0.18$)$ \\
\hline Perception of weight (about the right weight vs not) & 6.06 & $<.001$ & $.09(0.07$ to 0.13$)$ \\
\hline Physical activity (IPAQ ${ }^{b}$ ) & -0.03 & .97 & $.00(-0.02$ to 0.02$)$ \\
\hline Psychological distress $\left(\mathrm{K} 10^{\mathrm{c}}\right)$ & 9.45 & $<.001$ & $.21(0.01$ to 0.01$)$ \\
\hline Suicidal ideation $\left(\mathrm{PSFS}^{\mathrm{d}}\right)$ & 0.38 & .71 & $.01(-0.03$ to 0.04$)$ \\
\hline Alcohol and/or other substance misuse & 2.82 & $<.001$ & .04 (0.01 to 0.04$)$ \\
\hline Days out of role & -1.42 & .16 & $-0.02(-0.01$ to 0.00$)$ \\
\hline Well-being $\left(\mathrm{PWI}^{\mathrm{e}}\right)$ & -3.37 & $<.001$ & -0.07 (0.00 to 0.00$)$ \\
\hline Happiness $\left(\mathrm{OHQ}^{\mathrm{f}}\right)$ & -0.40 & .69 & $-0.01(-0.01$ to 0.00$)$ \\
\hline Resilience $\left(\mathrm{BRCS}^{\mathrm{g}}\right.$ ) & 0.84 & .40 & $.01(0.00$ to 0.01$)$ \\
\hline Social support $\left(\mathrm{SSCS}^{\mathrm{h}}\right)$ & -1.39 & .16 & $-0.02(-0.01$ to 0.00$)$ \\
\hline Intimate bonds $\left(\mathrm{IBM}^{\mathrm{i}}\right)$ & -0.57 & .57 & $-0.01(0.00$ to 0.00$)$ \\
\hline Sex & 9.46 & $<.001$ & $.12(0.10$ to 0.15$)$ \\
\hline Age & -16.57 & $<.001$ & $-0.24(-0.01$ to -0.01$)$ \\
\hline
\end{tabular}

${ }^{\mathrm{a}} d f=15,4966$

bIPAQ: International Physical Activity Questionnaire short form.

${ }^{c}$ K10: 10-item Kessler Psychological Distress Scale.

${ }^{\mathrm{d}}$ PSFS: Psychiatric Symptom Frequency Scale.

${ }^{\mathrm{e}}$ PWI: Personal Well-being Index.

${ }^{f}$ OHQ: Oxford Happiness Questionnaire.

${ }^{g}$ BRCS: Brief Resilience Coping Scale.

${ }^{\mathrm{h}}$ SSCS: Schuster Social Support and Conflict Scale.

i IBM: Intimate Bond Measure.

When analyzed separately by age group (Multimedia Appendix 2), sex, current dieting status, perception of weight, and psychological distress consistently explained model variance across all age groups. Variation was found for happiness, alcohol or other substance misuse, and well-being items. Specifically, lower happiness also explained body image distress $(\beta=-0.16$; $P=.003$ ) in young people (aged 16-25 years). For those aged 26 to 49 years, alcohol and/or other substance misuse remained an item that explained body image distress $(\beta=.07 ; P=.008)$. Conversely, for the $\geq 50$ years age group, lower well-being continued to explain body image distress $(\beta=-0.10 ; P=.001)$ variance.

\section{Discussion}

\section{Principal Findings}

To our knowledge, this is the largest international study to examine body image distress - and other related factors, including self-reported and perceived weight range and dieting status - across time, age, and sex. Our findings show that body image distress has become a highly prevalent issue by 2015. Of concern, considerable levels of body image distress were present in women and young people, and multiple psychosocial risk factors were associated with this distress.

One of our key findings comes from the cross-sectional longitudinal Australian data. Self-reported body image distress in young people aged 16 to 25 years increased from $44.2 \%$ (414/949) of those surveyed in 2009 to three-quarters $(961 / 1278$, $75.19 \%$ ) in 2015 . This finding is consistent with the increasing 
prevalence rates of body image distress in countries such as the United States [1]. Furthermore, although there are some suggestions in the literature that concern regarding body image has increased in Australia [84-86], this is the first known study to report changes across these 3 time points using web-based samples. Our data indicate that the issue is much more prevalent. This increasing prevalence of body image distress corresponds with the rise of social media. During the time frame of the survey, Instagram was launched in 2010, Snapchat was released in 2011, and TikTok was released in 2016. As photographs and videos are central to the use of these platforms, and previous research has shown an association between body image distress and social media use, perhaps this increased level of distress has occurred in parallel with the rise of social media $[14,15]$.

This rise in prevalence is particularly concerning, given our findings that body image distress was associated with increased levels of current dieting, poorer self-perception of weight, higher psychological distress, increased alcohol or other substance misuse, and poorer personal well-being. This is consistent with previous research where higher body image dissatisfaction directly correlated with poor mental health-related quality of life and psychosocial functioning [17]. Furthermore, literature examining body appreciation has reported associations with greater subjective happiness [56] and fewer days of feeling mentally or physically unhealthy [87]. It is unclear whether these factors are precipitating factors or consequences of body image distress. As $24 \%$ of the variability in body image distress was accounted for by these factors, future research could endeavor to explore what other factors are potentially missing from this model that also contribute to distress, such as social media use or history of disordered eating. Overall, when considering the rise of body image distress and its link to poorer psychosocial outcomes, a sharper focus on this area is needed.

Another important finding was that in our 2015 international sample, more than half of the participants' BMI in the overweight or obese range $(59.34 \%)$, with men reporting higher levels of obesity than women. This in itself is concerning, as obesity is considered one of the greatest health epidemics worldwide [88-91]. Furthermore, our findings demonstrated a notable sex difference concerning how men and women perceive their weight compared with their self-reported weight as measured by BMI. Specifically, despite a higher percentage of men having an overweight or obese BMI, more women $(772 / 3339,23.12 \%)$ considered themselves to be very overweight than men $(351 / 2176,16.13 \%)$. Although more women in this sample were in a healthy weight range (women: 1344/3264, 41.19\%; men: $671 / 2115,31.73 \%$ ), only one-third of women believed they were about the right weight. This is consistent with data from previous studies demonstrating that women are more likely to perceive themselves as overweight compared with men [35,92-95]. In the literature, possible factors that may contribute to this discrepancy include self-esteem [96], sociocultural influences, and expectations [97-99].

Interventions in this area are relatively unexplored, particularly those targeting both men and women. Evidence-based interventions include self-monitoring, cognitive restructuring, exposure exercises, fitness training, mirror work [100], media literacy, self-esteem enhancement, and psychoeducation.
However, these interventions only achieve minor improvements in body image [101,102]. Interventions with a greater focus on stress management training, cognitions, and negative body image causes appear to be more effective [101]. There is some evidence that self-compassion training can be beneficial for weight loss, nutrition behaviors, eating behaviors, and body image [103]. This training focuses on promoting self-worth, creating a more positive body image, and decreasing body dissatisfaction, and may be the way forward to improve health outcomes in distressed individuals.

These discrepancies between actual and perceived weight were not only a function of sex but also of age. Our 2015 survey results indicated that $57.77 \%$ of young people were in the healthy BMI weight range-the highest endorsement across all age groups. Despite this, three-quarters of young people reported body image distress. Again, this was the highest endorsement across all age groups. As participants aged, their BMI increased-with far more in the overweight and obese categories. However, the rate of body image distress declined as participants aged, as did the influence of weight or shape on how they viewed themselves as a person. Previous literature supports this phenomenon [104-107]. This change could be attributed to a shift in body comparisons with age-appropriate peers [8], less cultural fat phobia [105-107], or a focus on body function rather than body appearance [108].

Furthermore, research has theorized that people's preoccupation and desire to change their body weight via dieting behavior becomes less salient with age [26]. Interestingly, our survey results demonstrated that approximately three-quarters of people reported they were not dieting, and this proportion remained relatively stable across each age group. Thus, although body image distress decreases with age, in line with the Webster and Tiggemann study [26], our contradictory finding is that dieting behaviors remain relatively consistent. Further research is needed to examine whether this is explained by the changes in people's reasons for dieting as they age. For example, older people might be dieting for health or medical reasons rather than because of their body image concerns.

\section{Implications for Policy and Practice}

This study supports the clear link between body image distress and poorer health and well-being [28]. Prevalence rates of body image dissatisfaction have increased worldwide in the past 30 years [109]. Our research shows that this prevalence is 3 in 4 young people when using a web-based survey methodology. These are compelling statistics. In 2019, the Australian government invested US \$146 million into the prevention, detection, assessment, and treatment of eating disorders [110]. Although this is timely, our findings on the inverse relationship between individual distress and psychosocial outcomes make a strong case for the need for prevention and early intervention before eating disorders emerge. This may include more comprehensive assessment when accessing health services and the use of health information technologies to improve support services [111]. Given our findings, such interventions may benefit from targeting across sex and age.

Previously, body image distress was thought to result from the discrepancy between actual and perceived body image. 
However, our results suggest that the rates of body image distress within some age groups far exceed the proportion of the population who experience a discrepancy, indicative of other factors contributing to distress. For example, research is needed to determine whether these results are related to the considerable increases in the use and availability of social media in the past decade [14]. Exposure to social media, particularly in an individual's formative years, could have a considerable impact on a young person's sense of self, quality of life, and body image than is currently known. Some studies have demonstrated that the use of highly visual social media such as Instagram or Snapchat is linked to upward social comparison and internalization of symptoms of body dysmorphia, resulting in increased body image distress [112-115]. The more time spent on social media, the more significant the body image concerns [116-118]. Photograph-based activity (eg, posting photographs and viewing or making comments on others' photographs) is particularly salient in contributing to body dissatisfaction and disordered eating [14]. As the data in this study were from a web-based sample recruited using social media channels, the results may reflect the experience of body image distress of a web-based population, who may be more likely to be using other platforms such as Instagram.

Body image distress and dieting behaviors are well understood to be risk factors for disordered eating and the development of an eating disorder. Our results indicate a relationship between dieting behavior, psychological distress, and the self-perception of weight, in addition to alcohol and/or other substance use and well-being impact on body image distress. The triangulation of items such as those used in this survey (BMI vs distress vs dieting status, or BMI vs distress vs perceptions of weight) may be beneficial as a brief screening tool. Given the burden of completing lengthy psychometrics, how these brief screeners compare with lengthier eating disorder questionnaires should be explored.

\section{Strengths and Limitations}

A key strength of this study is that it is one of the largest samples to date, providing data on weight, perceptions of weight, dieting status, body image distress, and health and well-being. As outlined in the main report's executive summary [69], a key limitation of the research is the nonepidemiological nature of the web-based research; targeting efforts were made for age, sex, and by country to address this. Although most individuals in the participating countries have widespread internet access [119], this study will also yield some level of internet bias, in that those who do not frequently access the internet or social media recruitment websites may not have participated. However, a major advantage to using a web-based surveying methodology is that previous research has found that it is associated with increased disclosure of sensitive information [120], such as the items asked in this survey. There is also the possibility of avidity bias occurring, as those with a greater interest in the subject may be more likely to participate [121]. However, overall, this research remains highly relevant, as it is the interactions between variables, not merely the statistical frequencies, that generate meaningful information. Furthermore, as we move further into the 21 st century, web-based questionnaires may become more the norm than the exception.

Where possible, measures that have been tested for reliability and validity across general populations worldwide were used. For example, the K10 is the standard tool used to measure distress in Australia's National Survey of Mental Health and Wellbeing (Burgess et al [122]) and is used widely in international studies. The BMI [121] is the most recommended and widely used tool for classifying weight range in adults [123]. However, the use of BMI is limited and has several deficiencies as a measure of obesity [124]. BMI is not a reliable reflection of health status, does not accurately reflect changes that occur with age, cannot account for muscle mass, and is a poor indicator of body fat percentage [123].

Furthermore, the participants were asked to self-report their height and weight. Responses may have been subject to bias as BMI is often calculated with overestimated height and underestimated weight data [125]. Furthermore, owing to the breadth and sheer size of the Global Health and Wellbeing Survey 2015, validated measures for eating disorders such as Eating Disorder Inventory, third edition [126] and the Eating Attitudes Test [127] were not viable to use. Instead, we asked brief questions (all adapted from established literature) on areas such as dieting status, perceptions of weight, and body image distress. Overall, the results are still meaningful. Although they may not be fully representative of the populations with eating disorders, they demonstrate a clear link between body image distress and health and well-being concerns.

\section{Conclusions}

This research demonstrates the significant interplay between body image distress and psychosocial risk factors, including currently dieting, worse perceptions of weight, elevated psychological distress, increased alcohol or other substance misuse, and poorer personal well-being. Considering that an increasing number of young people are experiencing body image distress, body image should be closely monitored, given its association with poorer health outcomes. Further research into tailored intervention and prevention strategies for those experiencing any level of body image distress, obesity, eating disorders, and other health-related concerns is needed.

\section{Acknowledgments}

The Global Health and Wellbeing 2015 Survey was commissioned by the Movember Foundation and conducted by the University of Sydney's Brain and Mind Centre and the Young and Well Cooperative Research Center (Young and Well Cooperative Research Centre: 2011-2016). The authors would like to acknowledge the respondents who consented to participate on the web in the Global Health and Wellbeing 2015 Survey; the international consortia for the Global Health and Wellbeing 2015 Survey, including Professor Sagar Parikh, Professor Richard Porter, Professor Jan Scott, and Dr Michael Rovito; the Movember Foundation (Australia) lead on the project Therese Fitzpatrick; and the Brain and Mind Centre team: Victoria Baldwin, Lisa Whittle, Django 
White, Laura Ospina Pinillos, Sarah Piper, Hannah Yee, and Frank Iorfino. The authors would also like to acknowledge the Young and Well CRC and headspace for the 2012 and 2009 data sets. The Movember Foundation commissioned this research. This project is also supported by philanthropic funding, for which donors are families affected by mental illness who wish to remain anonymous. This study was also funded by a National Health and Medical Research Council Australia Fellowship (No. 511921, awarded to IH).

\section{Conflicts of Interest}

IH was an inaugural Commissioner on Australia's National Mental Health Commission (2012-18). He is the codirector of Health and Policy at the Brain and Mind Centre (University of Sydney, Australia). The Brain and Mind Centre operates early-intervention youth services at Camperdown under contract to headspace. IH has previously led community-based and pharmaceutical industry-supported (Wyeth, Eli Lilly, Servier, Pfizer, and AstraZeneca) projects focused on the identification and better management of anxiety and depression. He was a member of the Medical Advisory Panel for Medibank Private until October 2017, a board member of Psychosis Australia Trust, and a member of the Veterans Mental Health Clinical Reference group. He is the chief scientific advisor to and a 5\% equity shareholder in InnoWell Pty Ltd. InnoWell was formed by the University of Sydney (45\% equity) and PwC (Australia; 45\% equity) to deliver the Aus \$30 (US \$22.2) million Australian government-funded Project Synergy (2017-20; a 3-year program for the transformation of mental health services) and lead transformation of mental health services internationally through the use of innovative technologies. JB is chair of the National Advisory Council for Open Arms, Veterans, and Families Counseling Service. She is a well-being and digital health consultant to Bupa, a member of the Veterans Mental Health Clinical Reference group, and a chief investigator and author of the Defense and Veterans Transition and Well-being Study. She is the founder of and an equity shareholder in InnoWell. She is a professor of Social Innovation and Chair of the Center for Mental Health at Swinburne University and an adjunct professor of Social Impact and Entrepreneurship at Royal Melbourne Institute of Technology. TD is now the director of Research \& Insights at the Australian Digital Health Agency. The other authors have no conflicts of interest to disclose.

\section{Multimedia Appendix 1}

Frequency statistics, chi-square, and analysis of variance comparing body image items by age and sex. [DOCX File, 24 KB-Multimedia Appendix 1]

\section{Multimedia Appendix 2}

Linear regression of body image distress by age group.

[DOCX File, 17 KB-Multimedia Appendix 2]

\section{Multimedia Appendix 3}

Pearson correlations of body image items with health and well-being measures for each age group.

[DOCX File, 15 KB-Multimedia Appendix 3]

\section{References}

1. Adams G, Turner H, Bucks R. The experience of body dissatisfaction in men. Body Image 2005 Sep;2(3):271-283. [doi: 10.1016/j.bodyim.2005.05.004] [Medline: 18089194]

2. Tiggemann M, Pickering AS. Role of television in adolescent women's body dissatisfaction and drive for thinness. Int $\mathbf{J}$ Eat Disord 1996 Sep;20(2):199-203. [doi: 10.1002/(SICI)1098-108X(199609)20:2<199::AID-EAT11>3.0.CO;2-Z] [Medline: 8863073]

3. Cash TF, Henry PE. Women's body images: the results of a national survey in the U.S.A. Sex Roles 1995 Jul;33(1-2):19-28. [doi: $10.1007 / \mathrm{bf01547933]}$

4. Peat CM, Peyerl NL, Muehlenkamp JJ. Body image and eating disorders in older adults: a review. J Gen Psychol 2008 Oct;135(4):343-358. [doi: 10.3200/GENP.135.4.343-358] [Medline: 18959226]

5. McCabe MP, Ricciardelli LA. Body image dissatisfaction among males across the lifespan: a review of past literature. $\mathrm{J}$ Psychosom Res 2004 Jun;56(6):675-685. [doi: 10.1016/S0022-3999(03)00129-6] [Medline: 15193964]

6. Cash TF. Body image: past, present, and future. Body Image 2004 Jan;1(1):1-5. [doi: 10.1016/S1740-1445(03)00011-1] [Medline: 18089136]

7. Cash TF, Szymanski ML. The development and validation of the Body-Image Ideals Questionnaire. J Pers Assess 1995 Jun;64(3):466-477. [doi: 10.1207/s15327752jpa6403 6] [Medline: 16367722]

8. Grogan S. Body Image: Understanding Body Dissatisfaction in Men Women and Children (Third Edition). Oxfordshire England: Routledge; Sep 29, 2016.

9. Mitchison D, Hay P, Griffiths S, Murray SB, Bentley C, Gratwick-Sarll K, et al. Disentangling body image: the relative associations of overvaluation, dissatisfaction, and preoccupation with psychological distress and eating disorder behaviors 
in male and female adolescents. Int J Eat Disord 2017 Feb;50(2):118-126 [FREE Full text] [doi: 10.1002/eat.22592] [Medline: 27539911]

10. Glashouwer KA, Bennik EC, de Jong PJ, Spruyt A. Implicit measures of actual versus ideal body image: relations with self-reported body dissatisfaction and dieting behaviors. Cognit Ther Res 2018;42(5):622-635 [FREE Full text] [doi: 10.1007/s10608-018-9917-6] [Medline: 30237650]

11. Kelley CC, Neufeld JM, Musher-Eizenman DR. Drive for thinness and drive for muscularity: opposite ends of the continuum or separate constructs? Body Image 2010 Jan;7(1):74-77. [doi: 10.1016/j.bodyim.2009.09.008] [Medline: 19944659]

12. Tiggemann M. Body image across the adult life span: stability and change. Body Image 2004 Jan;1(1):29-41. [doi: 10.1016/S1740-1445(03)00002-0] [Medline: 18089139]

13. Tiller E, Fildes J, Hall S. Youth survey report 2020. Mission Australia. URL: https://apo.org.au/node/309542 [accessed 2021-08-27]

14. Holland G, Tiggemann M. A systematic review of the impact of the use of social networking sites on body image and disordered eating outcomes. Body Image 2016 Jun;17:100-110. [doi: 10.1016/j.bodyim.2016.02.008] [Medline: 26995158]

15. Groesz LM, Levine MP, Murnen SK. The effect of experimental presentation of thin media images on body satisfaction: a meta-analytic review. Int J Eat Disord 2002 Jan;31(1):1-16. [doi: 10.1002/eat.10005] [Medline: 11835293]

16. Weinberger N, Kersting A, Riedel-Heller SG, Luck-Sikorski C. Body dissatisfaction in individuals with obesity compared to normal-weight individuals: a systematic review and meta-analysis. Obes Facts 2016;9(6):424-441 [FREE Full text] [doi: 10.1159/000454837] [Medline: 28013298]

17. Wilson RE, Latner JD, Hayashi K. More than just body weight: the role of body image in psychological and physical functioning. Body Image 2013 Sep;10(4):644-647. [doi: 10.1016/j.bodyim.2013.04.007] [Medline: 23726517]

18. Friedman K, Reichmann S, Costanzo P, Musante G. Body image partially mediates the relationship between obesity and psychological distress. Obes Res 2002 Jan;10(1):33-41 [FREE Full text] [doi: 10.1038/oby.2002.5] [Medline: 11786599]

19. Kantanista A, Król-Zielińska M, Borowiec J, Osiński W. Is underweight associated with more positive body image? Results of a cross-sectional study in adolescent girls and boys. Span J Psychol 2017 Feb 09;20:E8. [doi: 10.1017/sjp.2017.4] [Medline: 28181473]

20. Sarwer DB, Thompson JK, Cash TF. Body image and obesity in adulthood. Psychiatr Clin North Am 2005 Mar;28(1):69-87, viii. [doi: 10.1016/j.psc.2004.09.002] [Medline: 15733612]

21. Allaz A, Bernstein M, Rouget P, Archinard M, Morabia A. Body weight preoccupation in middle-age and ageing women: a general population survey. Int J Eat Disord 1998 Apr;23(3):287-294. [doi:

10.1002/(sici)1098-108x(199804)23:3<287::aid-eat6>3.0.co;2-f] [Medline: 9547663 ]

22. Thompson JK, Stice E. Thin-ideal internalization: mounting evidence for a new risk factor for body-image disturbance and eating pathology. Curr Dir Psychol Sci 2001 Oct 1;10(5):181-183. [doi: 10.1111/1467-8721.00144]

23. Watkins JA, Christie C, Chally P. Relationship between body image and body mass index in college men. J Am Coll Health 2008;57(1):95-100. [doi: 10.3200/JACH.57.1.95-100] [Medline: 18682351]

24. Anderson D, Lundgren J, Shapiro J, Paulosky C. Weight goals in a college-age population. Obes Res 2003 Feb;11(2):274-278 [FREE Full text] [doi: 10.1038/oby.2003.41] [Medline: 12582224$]$

25. Runfola CD, Von Holle A, Peat CM, Gagne DA, Brownley KA, Hofmeier SM, et al. Characteristics of women with body size satisfaction at midlife: results of the Gender and Body Image (GABI) Study. J Women Aging 2013;25(4):287-304 [FREE Full text] [doi: 10.1080/08952841.2013.816215] [Medline: 24116991]

26. Webster J, Tiggemann M. The relationship between women's body satisfaction and self-image across the life span: the role of cognitive control. J Genet Psychol 2003 Jun;164(2):241-252. [doi: 10.1080/00221320309597980] [Medline: 12856818]

27. Rand CS, Wright BA. Continuity and change in the evaluation of ideal and acceptable body sizes across a wide age span. Int J Eat Disord 2000 Jul;28(1):90-100. [doi: 10.1002/(sici)1098-108x(200007)28:1<90::aid-eat11>3.0.co;2-p] [Medline: $\underline{10800018]}$

28. van den Berg PA, Mond J, Eisenberg M, Ackard D, Neumark-Sztainer D. The link between body dissatisfaction and self-esteem in adolescents: similarities across gender, age, weight status, race/ethnicity, and socioeconomic status. J Adolesc Health 2010 Sep;47(3):290-296 [FREE Full text] [doi: 10.1016/j.jadohealth.2010.02.004] [Medline: 20708569]

29. Cruz-Sáez S, Pascual A, Salaberria K, Echeburúa E. Normal-weight and overweight female adolescents with and without extreme weight-control behaviours: emotional distress and body image concerns. J Health Psychol 2015 Jun;20(6):730-740. [doi: 10.1177/1359105315580214] [Medline: 26032790]

30. Dooley B, Fitzgerald A, Giollabhui NM. The risk and protective factors associated with depression and anxiety in a national sample of Irish adolescents. Ir J Psychol Med 2015 Mar;32(1):93-105. [doi: 10.1017/ipm.2014.83] [Medline: 30185277]

31. Ferguson W, Goode M, Walsh A, Gavin P, Butler K. Evaluation of 4 weeks' neonatal antiretroviral prophylaxis as a component of a prevention of mother-to-child transmission program in a resource-rich setting. Pediatr Infect Dis J 2011 May;30(5):408-412. [doi: 10.1097/INF.0b013e31820614bd] [Medline: 21266939]

32. Kostanski M, Gullone E. Adolescent body image dissatisfaction: relationships with self-esteem, anxiety, and depression controlling for body mass. J Child Psychol Psychiatry 1998 Feb;39(2):255-262. [Medline: 9669238] 
33. Koronczai B, Kökönyei G, Urbán R, Kun B, Pápay O, Nagygyörgy K, et al. The mediating effect of self-esteem, depression and anxiety between satisfaction with body appearance and problematic internet use. Am J Drug Alcohol Abuse 2013 Jul;39(4):259-265. [doi: 10.3109/00952990.2013.803111] [Medline: 23841866]

34. Bélanger M, Marcotte D. Étude longitudinale du lien entre les changements vécus durant la transition primaire-secondaire et les symptômes dépressifs des adolescents. Can J Behav Sci/Revue canadienne des sciences du comportement 2013;45(2):159-172. [doi: 10.1037/a0025010]

35. Wardle J, Johnson F. Weight and dieting: examining levels of weight concern in British adults. Int J Obes Relat Metab Disord 2002 Aug;26(8):1144-1149. [doi: 10.1038/sj.ijo.0802046] [Medline: 12119582]

36. Stice E, Bearman SK. Body-image and eating disturbances prospectively predict increases in depressive symptoms in adolescent girls: a growth curve analysis. Dev Psychol 2001 Sep;37(5):597-607. [doi: 10.1037//0012-1649.37.5.597] [Medline: 11552756 ]

37. Wichstrøm L, von Soest T. Reciprocal relations between body satisfaction and self-esteem: a large 13-year prospective study of adolescents. J Adolesc 2016 Feb;47:16-27. [doi: 10.1016/j.adolescence.2015.12.003] [Medline: 26713411]

38. Brausch AM, Muehlenkamp JJ. Body image and suicidal ideation in adolescents. Body Image 2007 Jun;4(2):207-212. [doi: 10.1016/j.bodyim.2007.02.001] [Medline: 18089266]

39. Brausch AM, Gutierrez PM. The role of body image and disordered eating as risk factors for depression and suicidal ideation in adolescents. Suicide Life Threat Behav 2009 Feb;39(1):58-71. [doi: 10.1521/suli.2009.39.1.58] [Medline: 19298151]

40. Orbach I, Stein D, Shan-Sela M, Har-Even D. Body attitudes and body experiences in suicidal adolescents. Suicide Life Threat Behav 2001;31(3):237-249. [doi: 10.1521/suli.31.3.237.24250] [Medline: 11577910]

41. Orbach I, Gilboa-Schechtman E, Sheffer A, Meged S, Har-Even D, Stein D. Negative bodily self in suicide attempters. Suicide Life Threat Behav 2006 Apr;36(2):136-153. [doi: 10.1521/suli.2006.36.2.136] [Medline: 16704320]

42. Miotto P, De Coppi M, Frezza M, Preti A. Eating disorders and suicide risk factors in adolescents: an Italian community-based study. J Nerv Ment Dis 2003 Jul;191(7):437-443. [doi: 10.1097/01.NMD.0000081590.91326.8B] [Medline: 12891090]

43. Forman M, Davis WN. Characteristics of middle-aged women in inpatient treatment for eating disorders. Eat Disord 2005;13(3):231-243. [doi: 10.1080/10640260590932841] [Medline: 16864530]

44. Klemchuk HP, Hutchinson CB, Frank RI. Body dissatisfaction and eating-related problems on the college campus: usefulness of the Eating Disorder Inventory with a nonclinical population. J Counsel Psychol 1990 Jul;37(3):297-305. [doi: 10.1037/0022-0167.37.3.297]

45. Tylka T. The relation between body dissatisfaction and eating disorder symptomatology: an analysis of moderating variables. J Counsel Psychol 2004 Apr;51(2):178-191. [doi: 10.1037/0022-0167.51.2.178]

46. Griffiths S, Hay P, Mitchison D, Mond JM, McLean SA, Rodgers B, et al. Sex differences in the relationships between body dissatisfaction, quality of life and psychological distress. Aust N Z J Public Health 2016 Dec;40(6):518-522. [doi: 10.1111/1753-6405.12538] [Medline: 27372301]

47. Kendzor DE, Adams CE, Stewart DW, Baillie LE, Copeland AL. Cigarette smoking is associated with body shape concerns and bulimia symptoms among young adult females. Eat Behav 2009 Jan;10(1):56-58 [FREE Full text] [doi: 10.1016/j.eatbeh.2008.10.012] [Medline: 19171320]

48. Nelson M, Lust K, Story M, Ehlinger E. Alcohol use, eating patterns, and weight behaviors in a university population. Am J Health Behav 2009;33(3):227-237. [doi: 10.5993/ajhb.33.3.1] [Medline: 19063644]

49. Corning AF, Krumm AJ, Smitham LA. Differential social comparison processes in women with and without eating disorder symptoms. J Counsel Psychol 2006;53(3):338-349. [doi: 10.1037/0022-0167.53.3.338]

50. Green SP, Pritchard ME. Predictors of body image dissatisfaction in adult men and women. Soc Behav Pers 2003 Jan 01;31(3):215-222. [doi: 10.2224/sbp.2003.31.3.215]

51. Alleva JM, Martijn C, Veldhuis J, Tylka TL. A Dutch translation and validation of the Body Appreciation Scale-2: an investigation with female university students in the Netherlands. Body Image 2016 Dec;19:44-48. [doi: 10.1016/j.bodyim.2016.08.008] [Medline: 27598764]

52. Dalley SE, Vidal J. Optimism and positive body image in women: the mediating role of the feared fat self. Pers Individ Dif 2013 Sep;55(5):465-468. [doi: 10.1016/j.paid.2013.04.006]

53. Marta-Simões J, Ferreira C, Mendes AL. Exploring the effect of external shame on body appreciation among Portuguese young adults: the role of self-compassion. Eat Behav 2016 Dec;23:174-179. [doi: 10.1016/j.eatbeh.2016.10.006] [Medline: $\underline{27816855}$

54. Raque-Bogdan TL, Piontkowski S, Hui K, Ziemer KS, Garriott PO. Self-compassion as a mediator between attachment anxiety and body appreciation: an exploratory model. Body Image 2016 Dec;19:28-36. [doi: 10.1016/j.bodyim.2016.08.001] [Medline: 27597725]

55. Stokes R, Frederick-Recascino C. Women's perceived body image: relations with personal happiness. J Women Aging 2003;15(1):17-29. [doi: 10.1300/J074v15n01_03] [Medline: 12678183]

56. Swami V, Ng S. Factor structure and psychometric properties of the Body Appreciation Scale-2 in university students in Hong Kong. Body Image 2015 Sep;15:68-71. [doi: 10.1016/j.bodyim.2015.06.004] [Medline: 26189168]

57. Swami V, Ng S, Barron D. Translation and psychometric evaluation of a Standard Chinese version of the Body Appreciation Scale-2. Body Image 2016 Sep;18:23-26. [doi: 10.1016/j.bodyim.2016.04.005] [Medline: 27236474] 
58. Swami V, Tran US, Stieger S, Voracek M, The YouBeauty.com Team 2015. Associations between women's body image and happiness: results of the YouBeauty.com Body Image Survey (YBIS). J Happiness Stud 2014 Apr 26;16(3):705-718. [doi: $10.1007 / \mathrm{s} 10902-014-9530-7]$

59. Swami V, Weis L, Barron D, Furnham A. Positive body image is positively associated with hedonic (emotional) and eudaimonic (psychological and social) well-being in British adults. J Soc Psychol 2018;158(5):541-552. [doi: 10.1080/00224545.2017.1392278] [Medline: 29053404]

60. Tylka TL, Van Diest AM. The Intuitive Eating Scale-2: item refinement and psychometric evaluation with college women and men. J Couns Psychol 2013 Jan;60(1):137-153. [doi: 10.1037/a0030893] [Medline: 23356469]

61. Wasylkiw L, MacKinnon AL, MacLellan AM. Exploring the link between self-compassion and body image in university women. Body Image 2012 Mar;9(2):236-245. [doi: 10.1016/j.bodyim.2012.01.007] [Medline: 22406200]

62. Barker ET, Galambos NL. Body dissatisfaction of adolescent girls and boys:: risk and resource factors. J Early Adolesc 2003 May 1;23(2):141-165. [doi: 10.1177/0272431603023002002]

63. Bearman SK, Martinez E, Stice E, Presnell K. The skinny on body dissatisfaction: a longitudinal study of adolescent girls and boys. J Youth Adolesc 2006 Apr;35(2):217-229 [FREE Full text] [doi: 10.1007/s10964-005-9010-9] [Medline: 16912810]

64. Stice E, Whitenton K. Risk factors for body dissatisfaction in adolescent girls: a longitudinal investigation. Dev Psychol 2002 Sep;38(5):669-678. [doi: 10.1037//0012-1649.38.5.669] [Medline: 12220046]

65. Close S, Smaldone A, Fennoy I, Reame N, Grey M. Using information technology and social networking for recruitment of research participants: experience from an exploratory study of pediatric Klinefelter syndrome. J Med Internet Res 2013 Mar 19;15(3):e48 [FREE Full text] [doi: 10.2196/jmir.2286] [Medline: 23512442]

66. Merolli M, Gray K, Martin-Sanchez F. Therapeutic affordances of social media: emergent themes from a global online survey of people with chronic pain. J Med Internet Res 2014 Dec 22;16(12):e284 [FREE Full text] [doi: 10.2196/jmir.3494] [Medline: 25533453]

67. Bhutta CB. Not by the book: Facebook as a sampling frame. Sociol Methods Res 2012 Mar 21;41(1):57-88. [doi: $10.1177 / 0049124112440795]$

68. Biernacki P, Waldorf D. Snowball sampling: problems and techniques of chain referral sampling. Sociol Methods Res 1981 Nov;10(2):141-163. [doi: 10.1177/004912418101000205]

69. Burns J, Davenport T, Milton AI. Men's health and wellbeing in Australia, Canada, New Zealand, the United Kingdom and United States: findings from an international online pilot survey. The Movember Foundation. URL: https://cdn. movember.com/uploads/images/2017/Our\%20Work/Publications/Mens Health Survey Executive Summary FA.pdf [accessed 2021-08-27]

70. Blashill AJ, Wilhelm S. Body image distortions, weight, and depression in adolescent boys: longitudinal trajectories into adulthood. Psychol Men Masc 2014;15(4):445-451 [FREE Full text] [doi: 10.1037/a0034618] [Medline: 25383047]

71. Burns J, Christensen H, Luscombe G. Game on: exploring the impact of technologies on young men's mental health and wellbeing. Young and Well Cooperative Research Centre. URL: https://www.researchgate.net/publication/ 303812662 Game On Exploring the Impact of Technologies on Young Men's Mental Health and Wellbeing [accessed 2021-08-27]

72. Craig CL, Marshall AL, Sjöström M, Bauman AE, Booth ML, Ainsworth BE, et al. International physical activity questionnaire: 12-country reliability and validity. Med Sci Sports Exerc 2003 Aug;35(8):1381-1395. [doi: 10.1249/01.MSS.0000078924.61453.FB] [Medline: 12900694]

73. Kessler RC, Demler O, Frank RG, Olfson M, Pincus HA, Walters EE, et al. Prevalence and treatment of mental disorders, 1990 to 2003. N Engl J Med 2005 Jun 16;352(24):2515-2523 [FREE Full text] [doi: 10.1056/NEJMsa043266] [Medline: 15958807]

74. Psychological distress. Australian Bureau of Statistics. 2012. URL: https://www.abs.gov.au/ausstats/abs@.nsf/Lookup/ by\%20Subject/4364.0.55.001 2014-15 Main\%20Features Psychological\%20distress 16 [accessed 2021-09-08]

75. Lindelow M, Hardy R, Rodgers B. Development of a scale to measure symptoms of anxiety and depression in the general UK population: the psychiatric symptom frequency scale. J Epidemiol Community Health 1997 Oct;51(5):549-557 [FREE Full text] [doi: 10.1136/jech.51.5.549] [Medline: 9425466]

76. Von Korff M, Ustun T, Ormel J, Kaplan I, Simon GE. Self-report disability in an international primary care study of psychological illness. J Clin Epidemiol 1996 Mar;49(3):297-303. [doi: 10.1016/0895-4356(95)00512-9] [Medline: 8676177]

77. Personal wellbeing index. Australian Centre on Quality of Life. URL: http://www.acqol.com.au/index [accessed 2021-08-27]

78. Hills P, Argyle M. The Oxford Happiness Questionnaire: a compact scale for the measurement of psychological well-being. Pers Individ Dif 2002 Nov;33(7):1073-1082. [doi: 10.1016/s0191-8869(01)00213-6]

79. Sinclair VG, Wallston KA. The development and psychometric evaluation of the Brief Resilient Coping Scale. Assessment 2004 Mar;11(1):94-101. [doi: 10.1177/1073191103258144] [Medline: 14994958]

80. Schuster T, Kessler R, Aseltine R. Supportive interactions, negative interactions, and depressed mood. Am J Community Psychol 1990 Jun;18(3):423-438. [doi: 10.1007/BF00938116] [Medline: 2264558]

81. Kaplan RM, Chambers DA, Glasgow RE. Big data and large sample size: a cautionary note on the potential for bias. Clin Transl Sci 2014 Aug;7(4):342-346 [FREE Full text] [doi: 10.1111/cts.12178] [Medline: 25043853] 
82. Milton AC, Davenport TA, Iorfino F, Flego A, Burns JM, Hickie IB. Suicidal thoughts and behaviors and their associations with transitional life events in men and women: findings from an international web-based sample. JMIR Ment Health 2020 Sep 11;7(9):e18383 [FREE Full text] [doi: 10.2196/18383] [Medline: 32915160]

83. Milton AC, La Monica H, Dowling M, Yee H, Davenport T, Braunstein K, et al. Gambling and the role of resilience in an international online sample of current and ex-serving military personnel as compared to the general population. J Gambl Stud 2020 Jun;36(2):477-498. [doi: 10.1007/s10899-019-09900-w] [Medline: 31620927]

84. Buckley H, Dalton B, Fildes J, Ivancic L, Matkovic L, Perrens B, et al. Youth Survey 2012. Mission Australia. URL: https:/ /www.missionaustralia.com.au/publications/youth-survey/73-mission-australia-youth-survey-2012/file [accessed 2021-08-27]

85. Carlisle E, Fildes J, Hall S, Hicking V, Perrens B, Plummer J. Youth Survey Report 2018. Mission Australia. URL: https:/ lapo.org.au/node/206361 [accessed 2021-08-27]

86. Mission Australia's 2014 Youth Survey Report. Mission Australia. URL: https://www.ncsehe.edu.au/publications/ mission-australia-youth-survey-2014/ [accessed 2021-08-27]

87. Muennig P, Jia H, Lee R, Lubetkin E. I think therefore I am: perceived ideal weight as a determinant of health. Am J Public Health 2008 Mar;98(3):501-506. [doi: 10.2105/AJPH.2007.114769] [Medline: 18235062]

88. GBD 2015 Obesity Collaborators, Afshin A, Forouzanfar MH, Reitsma MB, Sur P, Estep K, et al. Health effects of overweight and obesity in 195 countries over 25 years. N Engl J Med 2017 Jul 06;377(1):13-27 [FREE Full text] [doi: 10.1056/NEJMoa1614362] [Medline: 28604169]

89. Friedrich M. Global obesity epidemic worsening. J Am Med Assoc 2017 Aug 15;318(7):603. [doi: 10.1001/jama.2017.10693] [Medline: 28810033]

90. Wadden T, Womble L, Stunkard A, Anderson D. Psychosocial consequences of obesity and weight loss. In: Wadden TA, Stunkard AJ, editors. Handbook of Obesity Treatment. New York: Guilford Press; 2004:1-624.

91. World Health Organization. Obesity: preventing and managing the global epidemic. Report of a WHO consultation. World Health Organ Tech Rep Ser 2000;894:i-xii, 1-253. [Medline: 11234459]

92. Bish CL, Blanck HM, Maynard LM, Serdula MK, Thompson NJ, Khan LK. Health-related quality of life and weight loss among overweight and obese U.S. adults, 2001 to 2002. Obesity (Silver Spring) 2006 Nov;14(11):2042-2053 [FREE Full text] [doi: $10.1038 /$ oby.2006.239] [Medline: 17135622$]$

93. Chang VW, Christakis NA. Self-perception of weight appropriateness in the United States. Am J Prev Med 2003 May;24(4):332-339. [doi: 10.1016/s0749-3797(03)00020-5] [Medline: 12726871]

94. Paeratakul S, Lovejoy J, Ryan D, Bray G. The relation of gender, race and socioeconomic status to obesity and obesity comorbidities in a sample of US adults. Int J Obes Relat Metab Disord 2002 Sep;26(9):1205-1210. [doi: 10.1038/sj.ijo.0802026] [Medline: 12187397]

95. Schieman S, Pudrovska T, Eccles R. Perceptions of body weight among older adults: analyses of the intersection of gender, race, and socioeconomic status. J Gerontol B Psychol Sci Soc Sci 2007 Nov;62(6):415-423. [doi: 10.1093/geronb/62.6.s415] [Medline: 18079430]

96. O'Dea JA, Abraham S. Improving the body image, eating attitudes, and behaviors of young male and female adolescents: a new educational approach that focuses on self-esteem. Int J Eat Disord 2000 Jul;28(1):43-57. [doi: 10.1002/(sici)1098-108x(200007)28:1<43::aid-eat6>3.0.co;2-d] [Medline: 10800013]

97. Knauss C, Paxton SJ, Alsaker FD. Relationships amongst body dissatisfaction, internalisation of the media body ideal and perceived pressure from media in adolescent girls and boys. Body Image 2007 Dec;4(4):353-360. [doi:

10.1016/j.bodyim.2007.06.007] [Medline: 18089281]

98. Myers TA, Crowther JH. Sociocultural pressures, thin-ideal internalization, self-objectification, and body dissatisfaction: could feminist beliefs be a moderating factor? Body Image 2007 Sep;4(3):296-308. [doi: 10.1016/j.bodyim.2007.04.001] [Medline: $\underline{18089276]}$

99. Strahan EJ, Wilson AE, Cressman KE, Buote VM. Comparing to perfection: how cultural norms for appearance affect social comparisons and self-image. Body Image 2006 Sep;3(3):211-227. [doi: 10.1016/j.bodyim.2006.07.004] [Medline: 18089224]

100. Trentowska M, Bender C, Tuschen-Caffier B. Mirror exposure in women with bulimic symptoms: how do thoughts and emotions change in body image treatment? Behav Res Ther 2013 Jan;51(1):1-6. [doi: 10.1016/j.brat.2012.03.012] [Medline: 23168326]

101. Alleva JM, Sheeran P, Webb TL, Martijn C, Miles E. A meta-analytic review of stand-alone interventions to improve body image. PLoS One 2015 Sep 29;10(9):e0139177 [FREE Full text] [doi: 10.1371/journal.pone.0139177] [Medline: 26418470]

102. Ipser J, Sander C, Stein D. Pharmacotherapy and psychotherapy for body dysmorphic disorder. Cochrane Database Syst Rev 2009 Jan 21;2009(1):CD005332 [FREE Full text] [doi: 10.1002/14651858.CD005332.pub2] [Medline: 19160252]

103. Toole AM, Craighead LW. Brief self-compassion meditation training for body image distress in young adult women. Body Image 2016 Dec;19:104-112. [doi: 10.1016/j.bodyim.2016.09.001] [Medline: 27664531]

104. Pliner P, Chaiken S, Flett GL. Gender differences in concern with body weight and physical appearance over the life span. Pers Soc Psychol Bull 1990 Jun 1;16(2):263-273. [doi: 10.1177/0146167290162007]

105. Gadalla TM. Eating disorders and associated psychiatric comorbidity in elderly Canadian women. Arch Womens Ment Health 2008 Dec;11(5-6):357-362. [doi: 10.1007/s00737-008-0031-8] [Medline: 18791783] 
106. Lewis DM, Cachelin FM. Body image, body dissatisfaction, and eating attitudes in midlife and elderly women. Eat Disord 2001;9(1):29-39. [doi: 10.1080/106402601300187713] [Medline: 16864371]

107. McLaren L, Kuh D. Body dissatisfaction in midlife women. J Women Aging 2004;16(1-2):35-54. [doi: 10.1300/J074v16n01_04] [Medline: 15149923]

108. Reboussin BA, Rejeski WJ, Martin KA, Callahan K, Dunn AL, King AC, et al. Correlates of satisfaction with body function and body appearance in middle- and older aged adults: the activity counseling trial (ACT). Psychol Health 2000;15(2):239-254. [doi: 10.1080/08870440008400304]

109. Body image. National Eating Disorder Collaboration. URL: https://nedc.com.au/eating-disorders/eating-disorders-explained/ body-image/ [accessed 2021-08-27]

110. $\$ 70$ million for residential eating disorders treatment centres across Australia. Ministers Department of Health. URL: https:/ /www.health.gov.au/ministers/the-hon-greg-hunt-mp/media/

70-million-for-residential-eating-disorders-treatment-centres-across-australia [accessed 2021-08-27]

111. Milton AC, Hambleton A, Dowling M, Roberts AE, Davenport T, Hickie I. Technology-enabled reform in a nontraditional mental health service for eating disorders: participatory design study. J Med Internet Res 2021 Feb 16;23(2):e19532 [FREE Full text] [doi: 10.2196/19532] [Medline: 33591283]

112. Chrisler JC, Fung KT, Lopez AM, Gorman JA. Suffering by comparison: Twitter users' reactions to the Victoria's Secret Fashion Show. Body Image 2013 Sep;10(4):648-652. [doi: 10.1016/j.bodyim.2013.05.001] [Medline: 23769929]

113. Ghaznavi J, Taylor LD. Bones, body parts, and sex appeal: an analysis of \#thinspiration images on popular social media. Body Image 2015 Jun;14:54-61. [doi: 10.1016/j.bodyim.2015.03.006] [Medline: 25880783]

114. Lewallen J, Behm-Morawitz E. Pinterest or Thinterest?: social comparison and body image on social media. Soc Media Soc 2016 Mar 30;2(1):205630511664055. [doi: 10.1177/2056305116640559]

115. Perloff RM. Social media effects on young women's body image concerns: theoretical perspectives and an agenda for research. Sex Roles 2014 May 29;71(11-12):363-377. [doi: 10.1007/s11199-014-0384-6]

116. Marengo D, Longobardi C, Fabris M, Settanni M. Highly-visual social media and internalizing symptoms in adolescence: the mediating role of body image concerns. Comput Human Behav 2018 May;82:63-69. [doi: 10.1016/j.chb.2018.01.003]

117. Tiggemann M, Slater A. NetGirls: the Internet, Facebook, and body image concern in adolescent girls. Int J Eat Disord 2013 Sep;46(6):630-633. [doi: 10.1002/eat.22141] [Medline: 23712456]

118. Fardouly J, Diedrichs PC, Vartanian LR, Halliwell E. Social comparisons on social media: the impact of Facebook on young women's body image concerns and mood. Body Image 2015 Mar;13:38-45. [doi: 10.1016/j.bodyim.2014.12.002] [Medline: 25615425$]$

119. Chen W, Wellman B. The global digital divide-within and between countries. IT Society 2004 Mar;1(7):39-45 [FREE Full text]

120. Milton AC, Ellis LA, Davenport TA, Burns JM, Hickie IB. Comparison of self-reported telephone interviewing and web-based survey responses: findings from the second Australian young and well national survey. JMIR Ment Health 2017 Sep 26;4(3):e37 [FREE Full text] [doi: 10.2196/mental.8222] [Medline: 28951382]

121. Ethier RG, Poe GL, Schulze WD, Clark J. A comparison of hypothetical phone and mail contingent valuation responses for green-pricing electricity programs. Land Econ 2000 Feb;76(1):54-67. [doi: 10.2307/3147257]

122. Burgess PM, Pirkis JE, Slade TN, Johnston AK, Meadows GN, Gunn JM. Service use for mental health problems: findings from the 2007 National Survey of Mental Health and Wellbeing. Aust N Z J Psychiatry 2009 Jul;43(7):615-623. [doi: 10.1080/00048670902970858] [Medline: 19530018]

123. Nuttall F. Body mass index: obesity, BMI, and health: a critical review. Nutr Today 2015 May;50(3):117-128 [FREE Full text] [doi: 10.1097/NT.0000000000000092] [Medline: 27340299]

124. Rothman KJ. BMI-related errors in the measurement of obesity. Int J Obes (Lond) 2008 Aug;32 Suppl 3:56-59. [doi: 10.1038/ijo.2008.87] [Medline: 18695655]

125. Taylor A, Dal Grande E, Gill T, Chittleborough CR, Wilson DH, Adams RJ, et al. How valid are self-reported height and weight? A comparison between CATI self-report and clinic measurements using a large cohort study. Aust N Z J Public Health 2006 Jun;30(3):238-246. [doi: 10.1111/j.1467-842x.2006.tb00864.x] [Medline: 16800200]

126. Garner D. Eating Disorder Inventory. Third Edition. North Florida: PARInc; 2004.

127. Garner DM, Olmsted MP, Bohr Y, Garfinkel PE. The eating attitudes test: psychometric features and clinical correlates. Psychol Med 1982 Nov;12(4):871-878. [doi: 10.1017/s0033291700049163] [Medline: 6961471]

\section{Abbreviations}

K10: 10 -item Kessler Psychological Distress Scale 
Edited by $G$ Eysenbach; submitted 27.10.20; peer-reviewed by C Entwistle, S Six; comments to author 18.03.21; revised version received 13.05.21; accepted 31.05.21; published 04.11.21

Please cite as:

Milton A, Hambleton A, Roberts A, Davenport T, Flego A, Burns J, Hickie I

Body Image Distress and Its Associations From an International Sample of Men and Women Across the Adult Life Span: Web-Based Survey Study

JMIR Form Res 2021;5(11):e25329

URL: https://formative.jmir.org/2021/11/e25329

doi: $\underline{10.2196 / 25329}$

PMID:

(C)Alyssa Milton, Ashlea Hambleton, Anna Roberts, Tracey Davenport, Anna Flego, Jane Burns, Ian Hickie. Originally published in JMIR Formative Research (https://formative.jmir.org), 04.11.2021. This is an open-access article distributed under the terms of the Creative Commons Attribution License (https://creativecommons.org/licenses/by/4.0/), which permits unrestricted use, distribution, and reproduction in any medium, provided the original work, first published in JMIR Formative Research, is properly cited. The complete bibliographic information, a link to the original publication on https://formative.jmir.org, as well as this copyright and license information must be included. 